\title{
DIGESTIBILITY OF SOYBEAN OIL AND RAPE OIL BY SWINE
}

\author{
L. Paloheimo and Berit Jahkola \\ Department of Animal Husbandry, University of Helsinki
}

Received April 17, 1959

\section{Arrangement of the experiments}

The digestion experiment was made with two pigs (C and D) of the Large White Yorkshire breed. The animals were kept in separate concrete boxes. At the beginning of the experiment the weight of pig $\mathrm{C}$ was $53 \mathrm{~kg}$ and 52 days later at the close of the experiment $88 \mathrm{~kg}$. The corresponding figures for pig D were 60 and $92 \mathrm{~kg}$. The oil was given together with a basic ration which consisted of $2.6 \mathrm{~kg}$ skimmilk and $1.6 \mathrm{~kg}$ of a concentrate mixture, consisting of maize meal, wheat bran, and mineral mixture. The digestibility of the basic ration was first investigated. The digestibility of the oils was investigated on 3 different levels: $100 \mathrm{~g} 200 \mathrm{~g}$ and $300 \mathrm{~g}$ per day per animal. The animals received alternately soybean oil and rape oil. After the digestibility determination of the basic ration pig $\mathrm{C}$ received first soybean oil and pig D rape oil. The rape oil used was extracted from winter rape produced in Finland. The animals were fed twice daily, at 8.00 and 18.00 . No remnants were left. After the meals the troughs were filled with fresh water.

The $\mathrm{Cr}_{2} \mathrm{O}_{3}$ ratio technique was used. The samples of faeces for analysis were taken in the mornings of the 6th and 7 th day after the beginning of the feeding with $\mathrm{Cr}_{2} \mathrm{O}_{3}$ containing food. The fat was determined as ether extract.

\section{Results}

At the end of the last experimental period during which $300 \mathrm{~g}$ oil was given, pig D, which received soy bean oil, had diarrhoea. On the 7 th day of the period no sample of faeces could be taken from this animal and even the sample of the 6th day showed impaired digestion. Therefore, the corresponding digestibility coefficient was not included when average values were calculated. 
Table 1. Digestibility percentages for the total fat of the ration and for the added oil.

\begin{tabular}{cccccc}
\multicolumn{2}{c}{ Soy bean oil daily $\mathrm{g}$} & \multicolumn{3}{c}{ Rape oil daily g } \\
100 & 200 & 300 & 100 & 200 & 300
\end{tabular}

\begin{tabular}{ccccccc} 
& \multicolumn{7}{c}{ Digestibility percentages for total fat } \\
Pig C 6th day & 82,2 & 88.7 & 90.4 & 79.5 & 88.3 & 85.6 \\
D 7th & 81.0 & 88.4 & 90.6 & 80.7 & 88.3 & 84.6 \\
D th & 81.0 & 89.2 & $62.6^{1}$ & 80.4 & 87.2 & 87.2 \\
Average & 81.1 & 89.5 & - & 79.5 & 86.4 & 87.6 \\
& 81.4 & 89.0 & $90.5^{2}$ & 80.0 & 87.6 & 86.3
\end{tabular}

Digestibility percentage for oil

\begin{tabular}{ccccccccc} 
Pig C 6th day & 105.4 & 103.0 & 100.3 & 102.2 & 102.4 & 94.4 \\
" 7th & 104.6 & 102.6 & 100.6 & 104.2 & 102.3 & 93.2 \\
D 6th & 104.6 & 103.5 & $66.3^{1}$ & 104.4 & 101.0 & 96.4 \\
Average & & 104.8 & 104.1 & - & 102.2 & 99.9 & 96.9 \\
\hline
\end{tabular}

1 Diarrhoea 2 Pig D 6th day omitted.

The basic diet contained $4.0 \%$ fat. The average digestibility of it was $46.3 \%$ (44.5 in C and 48.1 in D). In calculating the digestibility percentages of the oils the share of the basic diet fat was subtracted from the total fat of the faeces.

Table 1 shows the digestibility percentages in the different periods separately for each animal and each day of sampling. It contains also the calculated average figures.

\section{Discussion}

In some rodents the digestibility of rape oil seems to be exceptionally low. In their experiments with rats DeUEL et al. (3, p. 308) observed that the digestibility percentage of crude rape oil was only 77 and that of refined oil 82 . CARROL (1, p. 202) reports the digestibility percentage 58 from experiments with rats and rabbits, and 61 from experiments with guinea pigs. According to Holmes, ref. Deuel, Jr. (2, p. 147) the digestibility of rape oil in man is about $99 \%$. Duel et al. (4, p. 369) in their experiments arrived at the same figure.

The results obtained from the experiments reported in this paper show that in pigs there is no marked difference in digestibility percentages between rape oil and soy bean oil. Both these oils are digested effectively. The fact that percentages somewhat over 100 are obtained is difficult to explain. One can hardly assume that the basic diet fat could have been digested more completely when given together with added oil. Similarly it is difficult to think that the excretion of endogenous lipids could have been less during the periods of oil feeding than in the basic feeding period. It is possible that some small experimental error is the cause of the too high percentages. However, the similarity in the completeness of the digestion of the two 
kinds of oils is evident. Increasing the oil allowances seems to result in a slight decrease in the digestibility. The digestibility of rape oil appears to be very slightly inferior to that of soy bean oil. The two experimental animals behaved very similarly during the different experimental periods with the exception of the $300 \mathrm{~g}$ soy bean period during which pig $\mathrm{D}$ had diarrhoea.

In the efficacy of rape oil digestion the swine seems to be comparable with man.

\section{$S u m m a r y$}

The digestion experiment was made with two pigs. The $\mathrm{Cr}_{2} \mathrm{O}_{3}$ ratio technique was used. The basic ration consisted of $2.6 \mathrm{~kg}$ skimmilk and $1.6 \mathrm{~kg}$ of a concentrate mixture. The animals received in alternate periods soybean oil and rape oil. The digestibility of the oils was investigated on 3 different levels: $100 \mathrm{~g}, 200 \mathrm{~g}$, and $300 \mathrm{~g}$ per day per animal. No significant difference in the digestibility of the two oils could be detected. The digestibility percentage was about 100. Increasing the oil allowances resulted in a slight decrease in the digestibility. The digestibility of rape oil appeared to be very slightly inferior to that of soybean oil.

\section{REF E R N C E S}

(1) Carrol, K. K. 1957. Rape oil and cholesterol metabolism in different species with reference to experimental atherosclerosis. Proc. Soc. Exptl. Biol. Med. 94: 202-205.

(2) Deuel, H. J., Jr. 1954. Nutritional significance of the fats. Progress in the chemistry of fats and other lipids. Edited by R. T. Holman \& W. O. Lundberg \& T. Malkin. 2: 99-192. London.

(3) Deuel, H. J., Jr., Greenberg, S. M., Straub, E. E. \& Jue, D. \& Gooding, C. M. \& Brown, C. F. 1948. Studies on the comparative nutritive value of fats, X. J. Nutrition 35 : $3101-314$.

(4) Deuel, H. J., Jr. Johnson, R. M., Calbert, C. E., Gardner, J. \& Thomas, B. 1949. Studies on the comparative nutritive value of fats, XII. J. Nutrition $38: 369-379$.

\section{S E L O S T U S:}

\section{SOIJAÖLJYN JA RYPSIÖLJYN SULAVUUS SIALLA}

\section{Paloheimo ja Berit Jahkola}

\section{Yliopiston kotieläintieteen laitos, Helsinki}

Eri tahoilla suoritetuissa tutkimuksissa on havaittu, että eräät jyrsijät sulattavat rypsiöljyä poikkeuksellisen huonosti. Sen sijaan on todettu, että sanotun öljyn ruoansulatuksellinen hyväksikäyttö ihmisellä on täysin normaalinen, t.s. sulavuus on lähes 100-prosenttinen. Selvittääkseen rypsiöljyn suhtautumista sian ruoansulatuskanavassa kirjoittajat suorittivat sulavuuskokeita sioilla. Koe-eläimille, joita oli kaksi, syötettiin kuoritusta maidosta, maissijauhosta ja vehnänleseistä kokoonpannun perusravinnon ohella vuorottaisina koejaksoina kasvavia määriä (100 g, $200 \mathrm{~g}$ ja $300 \mathrm{~g}$ päivässä) rypsiöljyä tai soijaöljyä. Perusannos sisälsi $4.0 \%$ rasvaa, jonka sulavuudeksi todettiin keskimäärin $46.3 \%$. Ottamalla huomioon perusannokseen sisältyvä rasva ja sen sulavuus, laskettiin lisättyjen öljyannoksien sulavuus. Todettiin, että molempien öljyjen sulavuus oli n. 100-prosenttinen. Rypsiöljyn sulavuus oli tuskin havaittavassa määrässä heikompi kuin soijaöljyn. Öljyannoksen asteittaista suurentamista seurasi mitättömän vähäinen sulavuuden huononeminen. Eri koe-eläimien antamat tulokset olivat mahdollisimman yhdenmukaiset. 